\title{
King Arthur in Medieval French Literature: History and Fiction, the Sense of the Tragic, and the Role of Dreams in La Mort le Roi Artu
}

Camelot, Avalon: it is enough to briefly mention such places to evoke a myth that has haunted European literature - and, more broadly, culture - for centuries. These are some of the places where the stories of King Arthur and the Round Table are located: places probably unreal, but places whose names form part of the European cultural imagination. In this sense, a very interesting representation is to be found in the French book La légende arthurienne, where a map - significantly entitled "carte de l'imaginaire arthurien" - shows both real places and imaginary ones, the latter existing only in literary sources. ${ }^{1}$ This tangled mix of reality and imagination is, in my view, the key element of the French medieval texts about King Arthur and the so-called "Breton cycle."2 My contribution will focus first more broadly on this literary tradition, and on its relationship with history and fiction. Thereafter, I will develop an analysis of these themes in the thirteenth-century French prose masterpiece La Mort le Roi Artu, focusing in particular on its sense of the tragic and on the role played by dreams in the text.

As suggested at the beginning, it is not overstated to define the character of King Arthur as a 'myth' of European culture. The trajectory of the theme of Arthur and the Round Table is a typically literary one. Still, its evolution is deeply embedded in historical developments and it has been repeatedly used for political legitimation. It also combines a key set of mythical and historical elements that remain a constant presence in European medieval culture. The charm this figure and the literary texts pertaining to the "Breton cycle" exercise on readers has a long history. In fact, the medieval public was already deeply aware of the seductive power of this kind of literature. For example, the French poet Jean Bodel distinguished three major literary materials - the texts of ancient Rome, the Carolingian ones from France, and the Breton cycle - and argued that the texts pertaining to the last are "vains et plaisantes," unreal and charming. ${ }^{3}$ And Dante Alighieri, in his De Vulgari Eloquentia, defined these texts as "Arthuri regis

1 Danielle Régnier-Bohler, editor. La légende arthurienne: Le Graal et la Table Ronde. Paris: Éditions Robert Laffont, 1989, pp. 1888-1889.

2 On this literary tradition, see Richard Trachsler. Clôtures du Cycle Arthurien: Étude et Textes. Geneva: Droz, 1996.

3 Régnier-Bohler, La légende arthurienne, p. II.

Ә Open Access. (C) 2019 Gaia Gubbini, published by De Gruyter. (๔) BY-NC-ND This work is licensed under the Creative Commons Attribution-NonCommercial-NoDerivatives 4.0 License. 
ambages pulcerrimae" ("the wonderful adventures of King Arthur"). ${ }^{4}$ One of the reasons for the irresistible charm of these texts is to be found in their peculiar relationship with imagination, space, and time. In fact, the fantastic imagery plays a crucial role in the narrative of Arthurian romances, where the presence of the supernatural is a key driver of the plot and deeply affects the characters' destiny. The relationship of these texts with time is also peculiar. ${ }^{5}$ The romances of the Breton cycle mostly have a cyclical view of time, which, following the Celtic tradition, is governed by the alternation of seasons, and is hybridized with the main Christian celebrations. ${ }^{6}$ These texts therefore give an impression of 'timelessness.' Mikhail Bakhtin, in his study "Forms of Time and of the Chronotope in the Novel" (1938), has already highlighted the "subjective play with time" of chivalric romances that distort temporal coordinates in the double direction of "a poetical and an emotional expansion and reduction." The same combination of imaginary and historical elements shapes the main character of the Breton cycle, King Arthur. In fact, whether the 'myth' of Arthur has a historical foundation or whether, on the contrary, it is a fictional one, is an issue that has caused rivers of ink to flow. Historians, archeologists, and literary historians have carefully analyzed the weak traces of the possible real existence of the king.

The name Arturus, referring to a military leader who successfully supported the Celtic Britons against the Saxons in the sixth century, appears very late, in ninth-century texts such as, for example, the Historia Brittonum written by Nennius. The fact that the name Arthur does not appear earlier, i.e. in sixthcentury chronicles - that is to say in texts that are contemporary to the historical struggle between Britons and Saxons -, combined with the fact that he is not even mentioned by the careful eighth-century Historia ecclesiastica gentis Anglorum written by the Venerable Bede, has led modern historians to doubt the historical existence of Arthur. ${ }^{8}$

4 Dante Alighieri. De vulgari eloquentia, edited by Steven Botterill. Cambridge: Cambridge University Press, 1996, I.10.2.

5 See Gaia Gubbini. "Le chronotope du sommeil-rêve dans les lais et dans les romans arthuriens français en vers." Forme del tempo e del cronotopo nelle letterature romanze e orientali (X convegno Società italiana di Filologia Romanza, VIII Colloquio internazionale Medioevo romanzo e orientale, Roma, 25-29 settembre 2012), edited by Gaetano Lalomia, Antonio Pioletti, Arianna Punzi, and Francesca Rizzo Nervo. Soveria Mannelli: Rubbettino, 2014, pp. 479-489.

6 For this cyclical conception of time and for all the considerations that follow on the historical discussion of the existence of King Arthur, see Philippe Walter. Arthur: L'ours et le roi. Paris: Imago, 2002, pp. 8-30.

7 Mikhail Bakhtin. Estetica e romanzo, translated by Clara Strada Janovic. Turin: Einaudi, 1979, pp. 301-302. The English translation is mine.

8 Walter, Arthur, p. 18. 
However, as Philippe Walter has persuasively observed, ${ }^{9}$ the importance of the figure of King Arthur is not to be found in his (highly dubious) historicity, but in the symbolic role he has played in European culture, especially from the twelfth century onward. ${ }^{10}$ At that time, the history of Arthur also had a political function: in this perspective, it is crucial to recall the alleged 'discovery' of Arthur's grave, promoted by Henry II, the first Plantagenet King of England, in Glastonbury Abbey, mistakenly identified with the Isle of Avalon - the island of apples, Arthur's last place of rest, according to literary texts. Such an operation was instrumental in consolidating the legitimacy of the Plantagenet kingdom, suggesting continuity between Arthur and Henry II and building on the appeal that the Arthurian tradition held for contemporaries. ${ }^{11}$ In fact, artistic and literary evidence attest to the European spread of the Arthurian legend; we may cite as an example the famous twelfth-century image on the mosaic pavement of the cathedral of Otranto, in the deep south of Italy, showing King Arthur riding a supernatural buck.

Among the textual sources, the Latin chronicle Historia regum Britanniae, written around 1135 by Geoffrey of Monmouth, is of particular importance. This text, together with its Anglo-Norman translation and re-elaboration entitled Roman de Brut (written by Wace in about 1155, i.e. 20 years later), ${ }^{12}$ plays a crucial role in the development of major Arthurian characters. ${ }^{13}$ Here, the wife of King Arthur, Guenièvre, is already part of an adulterous triangle that connects herself, her husband Arthur, and Mordret, who is the nephew and incestuous son of Arthur and his half-sister Morgan le Fay. Such an incestuous triangle is at the root of many medieval texts of Celtic origin - one is formed, for example, by Tristan, his uncle King Mark, and his uncle's wife Iseult the Blonde. This ancestral setting of love, power, and family relationships was entirely reframed by Chrétien de Troyes - a crucial author for the development and history of the Arthurian novel. ${ }^{14}$ In his famous twelfth-century verse romance Lancelot ou le chevalier de la Charrette, Chrétien in fact stages a character, Lancelot, destined for great popularity in the evolution of European literature. Lancelot, the most valiant knight of the Round Table, is in Chrétien's romance the lover of Guenièvre, replacing in

9 Ibid., p. 27.

10 On Arthur (and Charlemagne) as "roi imaginaire," see Dominique Boutet. Charlemagne et Arthur ou le roi imaginaire. Paris: Champion, 1992.

11 On the Plantagenet empire, see Martin Aurell. L'empire des Plantagenêts. Paris: Tempus, 2003.

12 On Wace, see Gioia Paradisi. Le passioni della storia: Scrittura e memoria nell'opera di Wace. Rome: Bagatto Libri, 2002.

13 Régnier-Bohler, La légende arthurienne, p. III.

14 For a full picture of Chrétien de Troyes and his masterpieces, see Chrétien de Troyes. Euvres complètes, edited by Daniel Poirion et al. Paris: Gallimard, 1994. 
the adulterous triangle the treacherous and incestuous character of Mordret and therefore reorganizing the narrative into a courtly - and more socially acceptable - framework. In the wake of Chrétien, this remains at the heart of the plot in the anonymous prose cycle called Lancelot-Graal: the narration of the exploits of King Arthur, Lancelot, and the Knights of the Round Table, and the adultery between Lancelot and Guenièvre, finally leading to the end of the Round Table. However, in the very last part of the so-called Lancelot-Graal cycle - that is to say in the thirteenth-century romance entitled La Mort le Roi Artu -, one may encounter not only the triangle formed by Arthur-Guenièvre-Lancelot, but once again the disquieting presence of Mordret. The text La Mort le Roi Artu - a somber, haunted text about the end of King Arthur and the Round Table - in fact presents itself as the perfect 'conclusion' of the Breton cycle. As Jean Frappier has importantly suggested, La Mort le Roi Artu is in fact conceived by the anonymous author as the 'epilogue' of the endless Arthurian tradition. ${ }^{15}$ Moreover, the three last masterpieces of the vast cycle called Lancelot-Graal - that is to say, the texts Lancelotpropre, Queste del Saint Graal, and La Mort le Roi Artu - have been recognized as the result of a coherent process of creation - especially thanks to the "thèse de l'architecte" developed by Jean Frappier. Frappier supposes that different authors contributed to the Lancelot-Graal cycle, but identifies, in analogy to what happened in the construction of the cathedrals during the Middle Ages, the presence of a "plan d'ensemble dans son unité," conceived by "celui qui mérite d'être appelé le premier maître de l'œuvre ou, d'un seul mot, l'Architecte.”16 The third and last part of such a 'triptych' and the final text of the entire cycle, La Mort le Roi Artu, stages the end of the Arthurian world with a tragic perception of the changes caused by time and, most of all, by the destructive power of the adulterous passion between Lancelot and Guenièvre. I will therefore now concentrate my attention on this text, and in particular on its sense of the tragic and on the role played by dreams in this masterpiece, adding some considerations on the concept of the tragic and on dream theories during the Middle Ages.

A brief summary of the key episodes of the plot of La Mort le Roi Artu will be useful for the remarks that follow. ${ }^{17}$ One of the brothers of Gauvain - King Arthur's favorite nephew - becomes aware of the relationship between Lancelot and Guenièvre: the two lovers, who, for a long time, have restrained their mutual passion, now experience it openly. Venomous rumors about this adulterous relationship circulate at

15 Jean Frappier. Étude sur La mort le roi Artu, roman du XIII siècle, dernière partie du "Lancelot" en prose. Geneva: Droz, 1961, spec. p. 9. The entire following section of my essay will rely on the excellent analysis of the text provided by Frappier.

16 Ibid., p. 144.

17 For a detailed summary, see ibid., pp. 9-20. 
court. A young and beautiful woman named "la demoiselle d'Escalot" (the Lady of Shalott) nurtures a passion for Lancelot, which he cannot requite as he is already deeply in love with the queen. However, at the start of her passion for the knight, the young woman does not know of his love affair with Guenièvre, and, following a topos widespread in Arthurian and Breton literature, the "don contraignant" - that is to say, according to the definition given by Philippe Ménard, the "don en blanc qui lie le donateur"18 -, she asks him to wear a sleeve of her dress at the tourney of Winchester as a courtly homage. Lancelot reluctantly accepts, nevertheless fearing Guenièvre's jealousy. Guenièvre, who does not know the real reason that has led Lancelot to wear the young woman's sleeve, indeed becomes terribly jealous and decides not to speak to him any more. Afterwards, accusations against Guenièvre develop at the court; she is finally condemned to be burned alive. In the meantime, the corpse of the "demoiselle d'Escalot," who died from the sorrow of not being loved by Lancelot, is magically transported by a ship without crew to Arthur's court, together with a letter explaining the reason for her death. Guenièvre and Lancelot's misunderstanding is therefore resolved, and Guenièvre's jealous rage disappears. The faithful Lancelot decides to rescue the queen from the fire; he saves her and they resume their adulterous relationship. The two lovers are discovered and leave Arthur's court together. A cruel war ensues, which sees Arthur and his nephew Gauvain fight against Lancelot. The latter is winning but generously returns the queen to the king. Arthur and Gauvain are still not satisfied and decide to continue the war. Lancelot has left the country and Arthur follows him, entrusting his kingdom and his wife Guenièvre to Mordret, his incestuous son. Mordret wants the kingdom and desires Guenièvre; he organizes a coup, spreading the word that Arthur has died. To escape Mordret, Guenièvre hides in the Tower of London. Arthur is fighting both Lancelot and the Romans; he learns of Mordret's betrayal and dreams of the Wheel of Fortune predicting his fall. He does not change course, however, nor does he ask for Lancelot's help. When he faces Mordred in the final battle, this results in the death of both and, in the end, of the Round Table.

As we can see already from this brief synopsis of the plot, the dominant note of the text La Mort le Roi Artu is the sense of the tragic, as Frappier has observed. ${ }^{19}$

18 See Philippe Ménard. "Le don en blanc qui lie le donateur: Réflexions sur un motif de conte.” An Arthurian Tapestry: Essays in Honor of Lewis Thorpe, edited by Kenneth Varty. Glasgow: Glasgow University Press, 1981, pp. 37-53. - On the same theme, see also Jean Frappier. Amour Courtois et Table Ronde. Geneva: Droz, 1973. A more recent study is Corinne Cooper-Deniau. "Culture cléricale et motif du 'don contraignant': Contre-enquête sur la théorie de l'origine celtique de ce motif dans la littérature française du XII ${ }^{\mathrm{e}}$ siècle et dans les romans arthuriens.” Le Moyen Âge 111 (2005), pp. 9-39. 19 Frappier, Étude, speaks of the "grandeur tragique de son sujet" (p. 25); in this regard, see also p. 253. 
Let us now review in detail some of the key themes that reflect this sense of the tragic in the text - that is to say, what from a modern perspective could be captured by the term "tragic."

A crucial theme for the development of the sense of the tragic in the text is the concept of inevitability that affects the destiny of characters, first of all, the inevitability of the force d'amors - the power of love. Near the beginning, the romance offers a bitter update on Lancelot's emotional troubles: having engaged in the Quest of the Holy Grail, he has renounced his passion for the queen for a long time. But even after such a chaste period, when he meets Guenièvre again he falls once more - and all of a sudden - into the old sin:

Mes comment que Lancelos se fust tenuz chastement [...] quant il fu en la queste del Seint Graal et eüst del tout renoiee la reïne Guenievre [...], si tost comme il fu venuz a cort, il ne demora pas un mois aprés que il fu autresi espris et alumez come il avoit onques esté plus nul jor, si qu'i rencheï el pechié de la reïne autresi comme il avoit fet autrefoiz. Et se il avoit devant meintenu celui pechié si sagement et si couvertement que nus ne s'en estoit aperceüz, si le meintint aprés si folement que Agravains [...] tant s'en prist garde que il le sot veraiement, que Lancelos amoit la reïne de fole amour et la reïne lui autresi. ${ }^{20}$

The inevitability of the adulterous relationship of Lancelot and Guenièvre - a risk many times avoided, but, in the end, openly taken by the two lovers - is a fil rouge that crosses the whole Lancelot-Graal cycle. However, this complex mixture of guilt and, at the same time, lack of resistance and shame which characterizes Lancelot and the queen is part of the psychological investigation present in particular in La Mort le Roi Artu. This amour fou between Lancelot and Guenièvre is at the root of many tragic episodes in the plot of the masterpiece: from the death of the valorous knights of King Arthur, to the sad story of the "demoiselle d'Escalot," and finally to the end of the Round Table, all of which occur under the tragic 'sign' of inevitability.

The “demoiselle d'Escalot," for example, is aware, despite her youth, that she could not avoid pursuing her passion for Lancelot (and thus escape her destiny of death), as she clearly states to her brother:

20 Jean Frappier, editor. La Mort le Roi Artu: Roman du XIII siècle. Genève: Droz, 1996, §4, p. 3. "When he was engaged in the Quest of the Holy Grail, Lancelot had lived in a state of perfect chastity [...]. He had then renounced the queen Guenièvre [...] but, once he returned to the court, within a month he was more than ever enflamed by his love for her. He thus fell again - as he did before - into the sin of loving the queen. But while in the past he committed his sin in such a cautious and hidden way that no one had realized it, after his return he madly allowed his sentiments to emerge openly, to the point that Agravain [...] followed the affair so well that he became certain that Lancelot loved the queen in a foolish love and that she felt the same for Lancelot.” 
Lors vint la damoisele a son frere et li descouvri meintenant trestout son pensé; et si li dist qu'ele amoit Lancelot de si grant amor que ele en estoit a la mort venue, se il ne fesoit tant qu'ele eüst toute sa volenté. [...] “car il m’est ensi destiné que je muire por lui; si en morrai que vos le verroiz apertement."21

Such an insistence on the inevitability of passion is a textual representation of the theme of lovesickness - a topos par excellence of medieval literature ${ }^{22}$ - and constitutes the perfect textual pendant of the "fole amour" already depicted with the couple Lancelot-Guenièvre. ${ }^{23}$ In fact, the young woman lets herself slowly die in bed, without offering resistance to her malady: "Lors se parti la damoisele devant lui et s'en vint a son lit et se cocha a tel ëur que onques puis s'en leva, se morte non, si com l'estoire le devisera apertement." ${ }^{24}$ The beauty of the "demoiselle d'Escalot" appears remarkable even after her death, but highly disquieting as her corpse suddenly appears at Arthur's court, transported by a ship without crew - this magic translation being another leitmotif of Breton literature..$^{25}$ Such a macabre apparition starts the series of episodes related to death that are present in the romance and that culminate in the final battle between father and son, gloriously staged by the anonymous author on Salisbury Plain. In fact, closely linked to the theme of death that permeates the entire text is the cosmic dimension which the death of King Arthur and the end of the Round Table acquire in La Mort le Roi Artu. The text clearly states that the sun-ray that shines through the wound of the traitor Mordret is a sign of God's wrath: "et l'estoire dit que aprés l'estordre del glaive passa par mi la plaie

21 Ibid., pp. 42-43. - "Then the young woman went to her brother and revealed to him all her thoughts. And she told him that she loved Lancelot so deeply that she would die if he did not agree to her having him at her will. [...] 'because it is my destiny, to die for him; I will die, and you will clearly see it."”

22 Among the rich bibliography on the theme, see Massimo Ciavolella. La "malattia d'amore" dall'Antichità al Medioevo. Rome: Bulzoni, 1976; Mary-Frances Wack. Lovesickness in the Middle Ages: The Viaticum and Its Commentaries. Philadelphia: University of Pennsylvania Press, 1990; Joachim Küpper. Petrarca: Das Schweigen der Veritas und die Worte des Dichters. Berlin: de Gruyter, 2002, esp. pp. 115-161. For updated and extensive bibliographical references on the subject, see also Gaia Gubbini. "Patologia amorosa: Due fenomeni nella lirica d'oîl." Ragionar d'amore: Il lessico delle emozioni nella lirica medievale, edited by Alessio Decaria and Lino Leonardi. Florence: Edizioni del Galluzzo per la Fondazione Ezio Franceschini, 2015, pp. 83-97.

23 "Lancelos amoit la reïne de fole amour et la reïne lui autresi" (Frappier, La Mort, p. 3).

24 Ibid., p. 68. - "Then she went away from him, she went to bed and lay down and from that time she would never get up but only dead, as the story will openly narrate."

25 For this topos, see Laurence Harf-Lancner. Les Fées au Moyen Age. Morgane et Mélusine: La naissance des fées. Paris: Champion, 1984. 
uns rais de soleill si apertement que Girflet le vit, dont cil del païs distrent que ce avoit esté sygnes de corrouz de Nostre Seigneur."26

The fatality and the inevitability that affect the destiny of characters are also elements crucial for Arthur. Two passages in particular seem to me to convey this inevitability: the dream of the Wheel of Fortune and the inscription on a rock on Salisbury Plain announcing that at that same site the final and tragic battle will take place. I will not comment on this second plot element, i.e. the inscription, which is introduced after the dream and, more importantly, after the idea of inevitability has already been strongly conveyed by the text. I will focus, rather, on the dream of the Wheel of Fortune. Arthur in fact has two dreams shortly before the battle of Salisbury. In the first one, Gauvain (who has recently been buried) appears to the king to dissuade him from engaging in the battle against Mordret - or, at least, to convince him to have Lancelot back by his side in order to defeat Mordret. In the dream, Arthur does not listen to Gauvain's advice. The night after this first dream, Arthur experiences another vision. A wondrous woman who embodies Fortune makes the king sit on her wheel and ultimately lets him fall to the ground; this dream is a prediction of his fall:

Quant il fu endormiz, il li fu avis que une dame venoit devant lui, la plus bele qu'il eüst onques mes veüe el monde, qui le levoit de terre et l'enportoit en la plus haute montaigne qu'il onques veïst; illuec l'asseoit seur une roe. En cele roe avoit sieges dont li un montoient et li autre avaloient; li rois regardoit en quel leu de la roe il estoit assis et voit que ses sieges estoit li plus hauz. La dame li demandoit: "Artus, ou ies tu? - Dame, fet-il, ge sui en une haute roe, mes ge ne sei quele ele est. - C'est, fet ele, la roe de la Fortune”. Lors li demandoit: "Artus, que voiz tu? - Dame, il me semble que ge voie tout le monde. - Voire, fet ele, tu le voiz, n'il n'i a granment chose dont tu n'aies esté sires jusques ci, et de toute la circuitude que tu voiz as tu esté li plus puissanz rois qui i fust. Mes tel sont li orgueil terrien qu'il n'i a nul si haut assiz qu'il ne le coviegne cheoir de la poesté del monde”. Et lors le prenoit et le trebuschoit a terre si felenessement que au cheoir estoit avis au roi Artu qu'il estoit touz debrisiez et qu'il perdoit tout le pooir del cors et des membres. ${ }^{27}$

26 Frappier, La Mort, §190, p. 245. - "The story says that, when King Arthur extracts his sword, a ray of sun goes through the wound with so much intensity that Girflet could see it; also the local people said that it was a sign of the wrath of God."

27 Ibid., §176, pp. 226-227. - "Once asleep, he had a vision: a lady got close to him, more beautiful than all the ladies he had seen before in this world; she raised him from the ground and took him to the top of the highest mountain he had ever seen. There she made him sit on a wheel provided with seats, which moved up and down as the wheel turned. Arthur, seeing where he was, saw that his seat was the highest of all. The lady asked him: 'Arthur, where are you?' 'My Lady, I am at the top of a high wheel, but I do not know which wheel is this one.' 'This is the wheel of fortune,' she said. And then she asked: 'Arthur, what do you see?' 'My Lady, it appears to me that I see the whole universe.' 'In truth,' she said, 'you do see it, and of all the kingdoms that you can 
We will come back soon to the sense of prophecy that Arthur's dream has in the text, framing the theme in the medieval cultural context regarding dreams. For the moment, it is crucial to highlight how the prophetic nature of Arthur's dream has to be understood as a part of the 'inevitability' which marks the character of the king in particular in La Mort le Roi Artu, and which contributes to generating the sense of the tragic we have analyzed so far. But what is the sense of the tragic for the Middle Ages? As analyzed by Henry Ansgar Kelly in his book on the conceptions of tragedy through the centuries - from Aristotle to the Middle Ages - the concept was already ductile in Antiquity, and even more so in Late Antiquity and during the medieval era. ${ }^{28}$ One well-known aspect, which is, however, crucial in the present context, is the fact that the concept of the tragic could apply to different literary genres, and not only to drama, and was mostly linked to the sublime in terms of the subject, style, and characters. What is perhaps even more important for our analysis of the tragic dimension of Arthur in La Mort le Roi Artu - and in particular of his dream of the Wheel of Fortune - is the strong role that the twelfth- and thirteenth-century concept of the tragic attributes to Fortune. ${ }^{29}$ For example, the long version of William of Conches' twelfth-century commentary on Boethius' Consolatio Philosophiae clearly highlights the close relationship between tragedy, the theme of Fortune, and the falls of "kings and highly placed men": "Quid tragediarum, etc. [...] In hoc carmine potuisti perpendere reges et provectos deprimi per Fortunam indiscrete percucientem, id est improvise, quia nescitur dies vel hora miseriarum.”30

Boethius found in tragedies, as William of Conches states in his Commentary, perfect examples of the mutability of Fortune, in fact: "Tragedia

see you have been the Lord; until now you have been the most powerful king that ever existed. But such is the pride of men that there is no one in the world, however highly placed he might be, that he should not fall down and lose his power over the world.' Then she took him and made him fall on the ground in such a treacherous way that, in his fall, the king felt like he had broken all his bones and had lost control of his body and limbs."

28 See Henry Ansgar Kelly. Ideas and Forms of Tragedy from Aristotle to the Middle Ages. Cambridge: Cambridge University Press, 1993, pp. xiii-xvi. On the specific theme of La Mort le Roi Artu as a tragedy, see Karen Pratt, who discusses the possible analogies between the medieval masterpiece and classical and late antique theories of tragedy: "Aristotle, Augustine or Boethius? La mort le roi Artu as Tragedy.” Nottingham French Studies 30 (1991), pp. 81-109.

29 On the relationship between Arthur and Fortune as a tragic theme, see Karl Joseph Höltgen. “König Arthur und Fortuna.” Anglia 75 (1957), pp. 35-54.

30 William of Conches, Glose super Librum Boecii de Consolacione, II.2, British Library MS Royal 15 B 3, fol. 39v., quoted in Kelly, Ideas and Forms of Tragedy, p. 71. For the English translation, see ibid.: "In this sort of poem [that is, tragedy], you could have taken to heart examples of kings and highly placed men brought down by Fortune's striking without discernment - that is without expectation, because one knows neither the day nor the hour of one's miseries." 
est scriptum de magnis iniquitatibus a prosperitate incipiens, in aduersitate desinens. Et est contraria comediae quae ab aliqua aduersitate incipiens in prosperitate finitur.”31

Like many authors in the twelfth century, John of Salisbury "considers the main feature of the tragedy to be the mournful ending," 32 and Geoffrey of Vinsauf summarizes this tradition, putting at the center of the concept of tragedy the misfortune of an eminent character. ${ }^{33}$ We will see how this element (the eminence of the character at the center of the fall) is also crucial for the medieval theory of dreams, in Macrobius as well as in the later tradition. The theme of the Wheel of Fortune is a frequent topos in medieval literature and, more broadly, culture, as scholars have highlighted. ${ }^{34}$ One beautiful example is to be found in the famous text of the Carmina Burana, 0 fortuna:

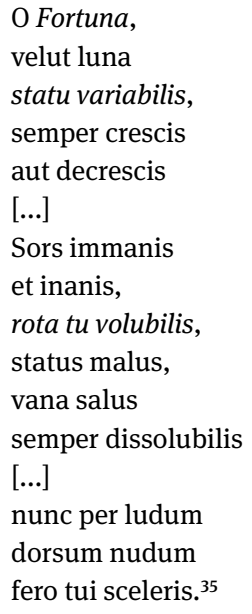

31 I quote this passage from the recent edition of the works of William de Conches by Édouard Jeauneau. See Guillelmi de Conchis Opera Omnia. Turnhout: Brepols, 1999, p. 105.

32 Kelly, Ideas, p. 80.

33 Ibid., p. 99.

34 On the subject in classical literature, see David M. Robinson. "The Wheel of Fortune." Classical Philology 41 (1946), pp. 207-216. For the relevance of the Wheel of Fortune in medieval literature, history of art and culture, see Edmond Faral. Recherches sur les sources latines des contes et romans courtois du moyen âge. Paris: Champion, 1913; Frappier, Étude, pp. 258-288; Yasmina Foehr-Janssens and Emmanuelle Métry, editors. La Fortune: thèmes, répresentations, discours. Geneva: Droz, 2003.

35 O Fortuna, CB 17, quoted in Alfons Hilka and Otto Schumann, editors. Carmina Burana. Heidelberg: Winter, 1930-1970. 
The theme is also widespread in illuminations in medieval manuscripts, and it is represented in manuscripts within the Arthurian tradition, ${ }^{36}$ very often presenting the detail of the bare back of man in his downfall, an element we have also encountered in the text of the Carmina Burana. As a perfect example, we can cite the illumination showing King Arthur on Fortune's wheel present in the manuscript London, British Library, Ms. Additional 10294, f. 89. ${ }^{37}$ Man helplessly facing his destiny is a medieval topos that reaches a particularly tragic degree in La Mort le Roi Artu, where we find concentrated all the relevant elements of the sublime: an eminent character, the Wheel of Fortune, the inevitability of destiny. Moreover, they are staged in a dramatic, narrative crescendo that culminates in the final battle where, as the texts says, "Einsi ocist li peres le fill, et li fils navra le pere a mort" ("the father killed his son and the son gave his father a mortal wound"). In this way the Round Table comes to its end, and Arthur's death leaves his kingdom "orphaned," as the prophecy inscribed on the rock on Salisbury Plain clearly announces: "En ceste plaingne doit estre la bataille mortel par quoi li roiaumes de Logres remeindra orfelins."38

As anticipated above, the tragic mood of Arthur's dream is not only conveyed by the presence of the tragic topos par excellence for the Middle Ages (the Wheel of Fortune), but also by the prophetic nature of the dream, which implies that all the predictions present in the vision will come true, regardless of the choices made by the king. However, in order to fully understand the meaning of such a prophetic dream in the plot of La Mort le Roi Artu, we have to contextualize it among the medieval theories about dreams. The distinction between dreams and visions is made, for example, by Augustine, especially in his De genesi ad litteram. In the twelfth book of this text, Augustine explains the formation of images and of visions and establishes a 'hierarchy' between different types of vision: the spiritual vision is superior to that of the body; in turn, the intellectual vision is superior to the spiritual one. ${ }^{39}$ According to this logic, "at its most powerful, imagination was thought to channel divine influence in the form of proph-

36 On the illuminations representing the dreams in Lancelot-Graal manuscripts, see Mireille Demaules and Christiane Marchello-Nizia. "Träume in der Dichtung: Die Ikonographie des Lancelot-Graal (13.-15. Jh.).” Träume im Mittelalter: Ikonologische Studien, edited by Agostino Paravicini Bagliani and Giorgio Stabile. Stuttgart: Belser, 1989, pp. 209-226.

37 The illumination can be seen here: http://www.bl.uk/catalogues/illuminatedmanuscripts/ ILLUMIN.ASP?Size=mid\&IllID=858. Accessed 25 July 2018.

38 Frappier, La Mort, p. 228. - "In this plain will take place the deadly battle after which the realm of Logres will become orphaned."

39 De genesi ad litteram, XII.24.51. 
ecy." ${ }^{40}$ However, medieval knowledge of dreams, as has been argued by Jacques Le Goff, ${ }^{41}$ largely draws on the typology of dreams in Macrobius' fifth-century Commentary on the Dream of Scipio and that in Calcidius' fourth-century Latin commentary on Plato's Timaeus. In the twelfth century, these ideas were developed by William of Conches and the School of Chartres ${ }^{42}$ - an important point of reference for the Troubadours and, more broadly, for the vernacular literary production of medieval France. ${ }^{43}$ Calcidius distinguished between the prophetic dream, the truthful dream, and the dream-lie. In his Commentary on the Dream of Scipio, Macrobius proposes a schema of five categories. I quote from Le Goff's seminal article:

Les rêves prémonitoires se répartissent en trois catégories: l'oneiros (somnium) ou rêve énigmatique, l'horama (visio) ou vision claire, le chrematismos (oraculum) ou rêve envoyé par la divinité et souvent énigmatique. Les rêves non prémonitoires se divisent en deux types: l'enupnion (insomnium), rêve, symbolique ou non, qui n’a de référence que dans le passé ou le quotidien, et le phantasma (visum), pure illusion. ${ }^{44}$

In the case of Arthur's dream ${ }^{45}$ of the Wheel of Fortune, it seems to me that we are at the crossroads between oraculum and visio: the dream is apparently enigmatic,

40 Quoted in Michelle Karnes. Imagination, Meditation, and Cognition in the Middle Ages. Chicago: University of Chicago Press, 2011, p. 6.

41 Jacques Le Goff. "Le christianisme et les rêves (II $-\mathrm{VII}{ }^{\mathrm{e}}$ siècle)." I sogni nel Medioevo: Seminario Internazionale (Roma, 2-4 ottobre 1983), edited by Tullio Gregory. Rome: Edizioni dell'Ateneo, 1985, pp. 171-218.

42 See the following studies: Alyson M. Peden. "Macrobius and Mediaeval Dream Literature.” Medium Aevum 54 (1985), pp. 59-73; Thomas Ricklin. Der Traum der Philosophie im 12. Jahrhundert: Traumtheorien zwischen Constantinus Africanus und Aristoteles. Leiden: Brill, 1998; Michel Lemoine. Intorno a Chartres: Naturalismo platonico nella tradizione cristiana del XII secolo. Milan: Jaca Book, 1998; Michel Lemoine and Clotilde Picard-Parra, editors. L'École de Chartres: Bernard de Chartres - Guillaume de Conches - Thierry de Chartres-- Clarembaud d'Arras. Théologie et cosmologie au XII siècle. Paris: Les Belles Lettres, 2004. - More broadly on the role of dreams in the Middle Ages, see I sogni nel Medioevo, edited by Tullio Gregory, passim; Steven F. Kruger. Dreaming in the Middle Ages. Cambridge: Cambridge University Press, 1992; Jean-Claude Schmitt. Le Corps, les rites, les rêves, le temps: Essais d'anthropologie médiévale. Paris: Gallimard, 2001.

43 In this regard, cf. Gaia Gubbini. "Soupir, esprit: Bernard de Ventadour, Can lo boschatges es floritz.” Romanistisches Jahrbuch 65/66 (2015), pp. 86-102.

44 Le Goff, "Le christianisme et les rêves," p. 178.

45 On the dreams in La Mort le Roi Artu, see Jehanne Joly. "Rêves prémonitoires et fin du monde arthurien.” Fin des temps et temps de la fin dans l'univers medieval. Aix-en-Provence: Centre universitaire d'études et de recherches médiévales d'Aix, 1993, pp. 259-284. - For a broader analysis of the dreams in the Lancelot-Graal cycle, see Klaus Speckenbach. "Form, Funktion und Bedeutung der Träume im Lancelot-Gral-Zyklus.” I sogni nel Medioevo, pp. 317-55. 
but clear enough to let Arthur realize, as soon as he awakes, that it constitutes a prophecy of the catastrophes to come ("Einsi vit li rois Artus les mescheances qui li estoient a venir”). ${ }^{46}$ Therefore, in La Mort le Roi Artu, the prophetic dream plays an important role in foreshadowing the narrative plot. Such a view of the dream as a prophecy that has to be trusted seems the antipode of the medieval literary topos of the dream-lie. In fact, in early French texts, dream-lies are especially present in courtly production, particularly in romances, where we find a frequent use of the rhyming pair songe/mençonge, as has been highlighted in the secondary literature..$^{47}$ Arthur's interpretation of the dream as a prophecy is furthermore confirmed by the priest who hears his confession in the morning after the vision. The fact that the king has correctly understood the meaning of the dream and that he has received a prophecy rather than a dream-lie probably has to do with his eminent status. As Le Goff has highlighted, Macrobius inherited from Antiquity (and then developed, and delivered to the Middle Ages) the concept of a "hierarchy of dreamers": according to such a hierarchy, "seuls peuvent être considérés comme rêves prémonitoires d'une authenticité irréfutable des rêves de personnages revêtus d'une autorité suprême." ${ }^{48}$ This is actually the case of Arthur, whom the same Fortune clearly designates in the text as "li plus puissanz rois qui i fust." 49

This theme - the dream-prophecy, or the vision that is reserved for an eminent character - seems significant for the understanding of the development

\footnotetext{
46 Frappier, La Mort, §177, p. 227. - "In this way King Arthur saw the misfortunes that were ready to come."

47 Within a rich bibliography, see at least Herman Braet. "Visio Amoris: Genèse et signification d'un thème de la poésie Provençale.” Mélanges d'Histoire littéraire, de Linguistique et de Philologie romanes offerts à Charles Rostaing. Liège: Association des romanistes de l'Université de Liège, 1974, pp. 89-99; Christiane Marchello-Nizia. "La rhétorique des songes et le songe comme rhétorique dans la littérature française médiévale.” I sogni nel Medioevo, pp. 244-259; Francesco Zambon. "L'amante onirica di Guglielmo IX," Romanistische Zeitschrift für Literaturgeschichte 15 (1991), pp. 247-261; Alain Corbellari and Jean-Yves Tilliette, editors. Le Rêve medieval. Geneva: Droz, 2007; Yasmina Foehr-Janssens. "Songes creux et insomnies dans les récits médiévaux (fabliaux, dits, exempla)." Le Rêve médiéval, edited by Alain Corbellari and Jean-Yves Tilliette. Geneva: Droz, 2007, pp. 111-136; Christine Ferlampin-Acher, Elisabeth Gaucher, and Denis Hüe, editors. Sommeil, songes et insomnies: Actes du colloque de Rennes (28-29 septembre 2006). Perspectives médiévales 32, supplement (2008); Mireille Demaules. La Corne et l'Ivoire: Étude sur le récit de rêve dans la littérature romanesque des XII ${ }^{e}$ et XIII ${ }^{e}$ siècles. Paris: Champion, 2010.

48 Le Goff, “Le christianisme et les rêves,” p. 183.

49 Frappier, La Mort, p. 227.
} 
of European medieval literature: from the revelations received by the saints ${ }^{50}$ and by Charlemagne, to the prophecy about the end of the Round Table given to Arthur, to the vision of the status animarum post mortem of Dante's Divine Comedy. ${ }^{51}$

50 See Alain Corbellari. "Pour une étude générique et synthétique du récit de rêve dans la littérature française médiévale.” Le Rêve médiéval, pp. 53-71.

51 In this regard, see Mirko Tavoni. “Dante 'Imagining' His Journey through the Afterlife.” Dante Studies 133 (2015), pp. 70-97. 